\title{
Analisis Faktor-Faktor yang Mempengaruhi Struktur Modal Perusahaan Barang Konsumsi di BEI tahun $2002-2011$
}

\author{
ANDI YOSHENDY, NOER A. ACHSANI, TB N. A. MAULANA \\ Program Pascasarjana Manajemen dan Bisnis Institut Pertanian Bogor, Bogor, Indonesia \\ Email Korespondensi: andiyos@gmail.com,achsani@yahoo.com,amet2001uk@yahoo.co.uk
}

\begin{abstract}
Abstrak
Tujuan dari studi empiris ini adalah untuk mengeksplorasi faktor yang mempengaruhi struktur modal perusahaan manufaktur barang konsumsi dan untuk menyelidiki apakah model struktur modal berdasarkan penelitian sebelumnya memberikan penjelasan yang meyakinkan untuk keputusan struktur modal dari companies. We Indonesia meninjau beberapateoristrukturmodal (trade-offteori, mematukteoriorder, teorikeagenan, danteorisinyal) untukmengidentifikasi faktor-faktor yang menentukan struktur modal bagi perusahaan barang konsumsi di Indonesia. Penelitian ini dilakukan dengan menggunakan prosedur data panel untuk sampel dari 29 perusahaan yang terdaftar di Bursa Efek Indonesia selama 2002-2011. Temuan ini menunjukkan bahwa profitabilitas dan berwujud terkait negatif dengan rasio hutang, ukuran dan usia terkait positif utang rasio, sedangkan pelindung pajak non-utang dan likuiditas tidak tampaknya terkait dengan rasio utang. Temuan mendukung sebagian besar teori pecking order untuk menjelaskan struktur modal perusahaan manufaktur barang konsumsi Indonesia. Temuan penelitian ini juga jelas menunjukkan pentingnya keputusan struktur modal untuk manajemen keuangan. Hal ini dapat membantu manajer untuk membuat keputusan struktur modal yang optimal.
\end{abstract}

Kata kunci: Struktur modal, bursa efek di Indonesia, barang-barang konsumen manufaktur

\section{Analysis of Factors Affecting Capital Structure Consumer Goods Company on BEI in 2002 - 2011}

\begin{abstract}
The objective of this empirical study is to explore factors affecting the capital structure of consumer goods manufacturing companies and to investigate whether the capital structure models based on prior researches provide convincing explanations for capital structure decisions of the Indonesian companies. We reviewed several capital structure theories (the trade-off theory, pecking order theory, agency theory, and signaling theory) to identify factors that determines capital structure for consumer goods companies in Indonesia. The research was conducted using panel data procedures for a sample of 29 companies that listed on the Indonesian Stock Exchange during 20022011.The findings suggest that profitability and tangibility are related negatively to the debt ratio, size and age are related positively to the debt ratio, while non-debt tax shields and liquidity do not appear to be related to debt ratio. The findings support mostly the pecking order theory to explain the capital structure of Indonesian consumer goods manufacturing companies. The findings of this research also clearly demonstrate the importance of capital structure decisions for financial management. This can help managers to make optimal capital structure decisions.
\end{abstract}

Keywords: Capital structure, Indonesian stock exchanges, consumer goods manufacturing 


\section{PENDAHULUAN}

Struktur modal merupakan salah satu topik penting di dalam literatur manajemen keuangan dan pembelanjaan perusahaan. Brealey et.al. (2011) menyatakan bahwa struktur modal merupakan satu dari tujuh topik yang paling penting di dalam ilmu pembelanjaan perusahaan. Struktur modal perusahaan terdiri dari hutang dan ekuitas (modal sendiri). Tujuan dari penentuan struktur modal adalah untuk memastikan biaya modal (cost of capital) yang paling rendah dan memaksimalkan kesejahteraan pemegang saham. Jadi struktur modal bertujuan mencari kombinasi yang optimal dari unsur modal yang harus ada untuk mencapai pengembalian (return) yang maksimal bagi pemegang saham.

Pada praktek di perusahaan, struktur modal dapat diukur dari rasio hutang dengan ekuitas (debt to equity ratio atau $D E R$ ). Nilai DER berbeda-beda di antara perusahaan dan jenis industri, sehingga $D E R$ dapat menjadi ukuran tingkat resiko perusahaan. Nilai DER lebih dari 1 menunjukkan unsur hutang di perusahaan lebih besar dari ekuitas dan nilai $D E R$ kurang dari 1 menunjukkan hal sebaliknya. Jika nilai DER kurang dari 1 maka resiko finansial perusahaan makin kecil di mana pembiayaan sebagian besar dari intern perusahaan.

Hasil penelitian Modigliani-Miller (1958) yang fenomenal merupakan dasar dari pembelanjaan perusahaan modern yang menunjukkan kondisikondisi dimana teori struktur modal tidak relevan, dan keputusan struktur modal tidak mempengaruhi nilai perusahaan. Proposisi MM berdasarkan asumsi seperti: tidak ada pajak, tidak ada pengaruh dari pasar, akses yang terbuka (symetric) kepada pemberi kredit, dan kebijakan perusahaan diasumsikan tidak memberikan sinyal apapun. Asumsi-asumsi tersebut yang pada akhirnya membuat proposisi MM ini tidak relevan karena di dunia nyata hal-hal ini tidak terbukti. Modigliani dan Miller (1963) melonggarkan asumsi tentang pajak untuk memperbaiki beberapa hal yang tidak relevan dari teori sebelumnya.

Dengan adanya pelonggaran asumsi pajak, terbukti model ini lebih efektif karena pembayaran bunga hutang dapat dikurangkan untuk pajak (tax-shield) dan meningkatkan nilai perusahaan. Di sisi lain, tambahan hutang menyebabkan naiknya kemungkinan terjadi kebangkrutan, sehingga struktur modal yang optimal merupakan tingkat pengungkitan (leverage) yang memberikan keseimbangan antara keuntungan dari pembiayaan hutang dan biaya kebangkrutan. Setelah teori MM, maka penelitian tentang faktor-faktor yang mempengaruhi struktur modal yang optimal makin banyak dilakukan.

Penelitian pada jurnal ini mengaitkan struktur modal perusahaan dengan keadaan perekonomian Indonesia sesudah krisis ekonomi 1998, yaitu periode pemulihan sampai dengan kurun waktu krisis finansial Eropa-AS tahun 2008. Indeks harga saham gabungan (IHSG) di Bursa Efek Indonesia (BEI) sejak tahun 2001 sampai dengan tahun 2007 secara konstan mengalami kenaikan tiap tahun sebesar $8 \%$ sampai tertinggi 63\%, sehingga pada 9 Januari 2008 IHSG mencapai titik tertinggi sebesar 2830.26. Sesudah itu IHSG mengalami penurunan (60\% sejak Januari 2008 sampai dengan rebound akhir tahun 2008), sebagian terindikasi karena adanya krisis finansial di Eropa-AS. Seluruh sektor industri di BEI pada periode tersebut mengalami penurunan, yang terbesar adalah sektor pertanian dengan penurunan sebesar $79 \%$ dan yang terendah adalah sektor barang konsumsi dengan penurunan hanya $46 \%$. Tingkat penurunan pada sektor barang konsumsi yang rendah ini menarik sebagai bahan kajian dikaitkan dengan struktur modal.

Industri barang konsumsi memproduksi barang kebutuhan konsumen seperti: makanan, minuman, kebutuhan rumah tangga, farmasi dan sebagainya, memiliki keuntungan dari faktor demografi jumlah penduduk dan basis konsumen besar seperti Indonesia. Dengan keuntungan ini, perusahaan barang konsumsi memiliki ketahanan tinggi terhadap krisis, tetapi masih tetap mengalami perubahan komposisi struktur modal. Hal ini terlihat dari hasil pengamatan terhadap DER bagi perusahaan publik (menurut klasifikasi Indonesia Capital Market Directory/ICMD) pada sektor makanan dan minuman (10 perusahaan), rokok (3 perusahaan) dan barang konsumer (3 perusahaan) selama tahun 2002 sampai dengan 2011. Selama kurun waktu tersebut, beberapa perusahaan mengalami fluktuasi DER dengan pola yang berbeda dari tahun-tahun sebelumnya (Gambar 1). 


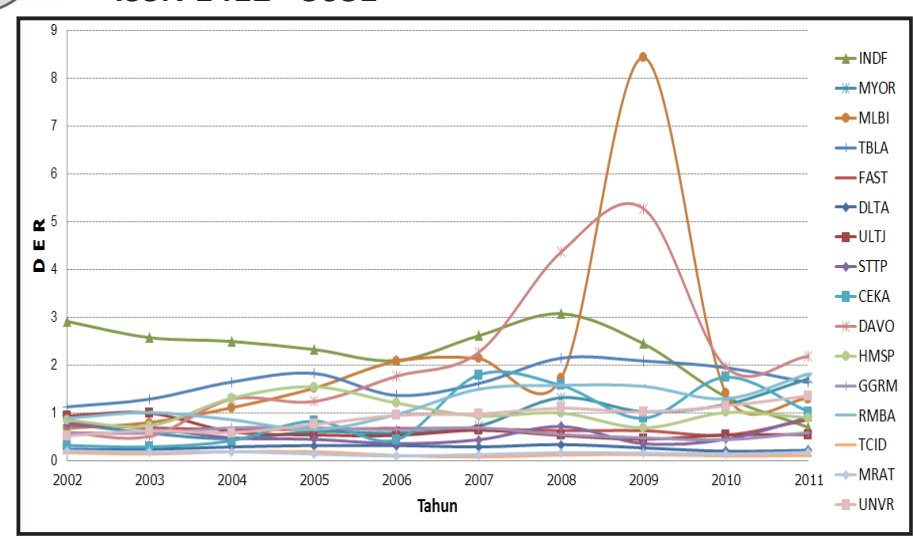

Gambar 1 DER atas beberapa emiten di sektor makanan dan minuman, rokok dan barang konsumer tahun 2002 sampai 2011

Pada kurun 2008 - 2010, perusahaan Multi Bintang Indonesia (MLBI) dan Davomas Abadi (DAVO) mengalami anomali kenaikan fluktuasi DER dibandingkan dengan tahun sebelumnya. MLBI pada tahun 2009 mencatat angka DER sebesar 8.44 yang sangat tinggi dibandingkan dengan tahun sebelumnya yang berkisar pada angka 1.4 sampai 2.6 saja. Hal ini disebabkan oleh kenaikan luar biasa kewajiban lancar dari Rp 561 milyar tahun 2008 menjadi Rp 852 milyar tahun 2009 (52\%) dan penurunan ekuitas dari Rp 344 milyar pada akhir 2008 menjadi Rp 105 milyar pada akhir 2009 (70\%) karena adanya pembayaran dividen interim sebesar Rp 263 milyar yang diumumkan bulan Desember 2009 dan telah dibayarkan bulan Januari 2010.

Sedangkan DAVO pada tahun yang sama mencatat DER sebesar 5.28, dibandingkan dengan tahun sebelumnya yang berkisar di angka 1.2 sampai 4.4. Hal ini disebabkan pada tahun 2009 DAVO mengalami gagal bayar hutang obligasi. Pada kondisi ini, berdasarkan perjanjian maka total utang pokok, bunga dan/atau denda obligasi dolar yang harus dibayarkan kepada para pemegang obligasi dolar menjadi jatuh tempo seketika dan dapat ditagih. Anomali dan fluktuasi pada struktur modal di perusahaan-perusahaan barang konsumsi semacam ini yang menarik untuk bahan awal penelitian.

Hal lain yang membuat struktur modal di sektor industri barang konsumsi menarik untuk dikaji karena sektor ini menjadi sektor yang memiliki daya tarik tinggi dan menjadi salah satu tujuan utama investor asing yang masuk ke Indonesia dalam bentuk Penanaman Modal Asing (PMA). Penelitian
Jurnal Bisnis \& Manajemen, 2015, Vol. XVI, No. 1, 47-59

atas struktur modal perusahaan barang konsumsi dalam kurun waktu yang panjang sejak sesudah krisis moneter 1998 sampai dengan sesudah krisis finansial AS - Eropa masih belum banyak dilakukan. Tujuan dari penelitian ini adalah memperkaya penelitian struktur modal secara spesifik di sektor industri barang konsumsi yang memiliki keunikan dan pada periode yang telah disebutkan di atas. Penelitian ini berusaha menjawab pertanyaan-pertanyaan berikut ini: (1) Bagaimana karakteristik struktur modal pada perusahaan barang konsumsi, yaitu perusahaan yang terdaftar di BEl tahun 2002 - 2011?. (2) Bagaimana pengaruh variabel profitabilitas, tangibilitas, ukuran perusahaan, NDTS, likuiditas dan usia perusahaan pada struktur modal perusahaan barang konsumsi di BEI tahun 2002 -2011, baik dilihat dari kewajiban total, kewajiban jangka pendek dan kewajiban jangka panjang?. (3) Apakah teori struktur modal pecking order atau trade-off juga berlaku bagi perusahaan barang konsumsi di BEI tahun 2002-2011?.

\section{KAJIAN LITERATUR}

Beberapa teori struktur modal telah dikembangkan untukmenentukanfaktorapa saja yang mempengaruhi struktur modal perusahaan. Seperti telah disebutkan pada bagian Pendahuluan, Modigliani dan Miller (1958) telah menempatkan suatu milestone atas penelitian struktur modal.

Pada proposisi yang pertama, Modigliani dan Miller (MM) menyatakan bahwa pasar sangat efisien jika tidak ada pajak. Hal ini mengakibatkan struktur modal dan keputusan modal tidak mempengaruhi biaya modal (cost of capital) atau nilai pasar atas saham perusahaan. Pada proposisi MM kedua, adanya hutang dan pembayaran bunga atas hutang (yang merupakan deductible expense) akan mengakibatkan turunnya dasar pengenaan pajak (tax base), sehingga biaya hutang (cost of debt) akan lebih kecil daripada biaya modal (cost of equity). Struktur modal yang optimal dapat dicapai dengan menentukan ekuilibrium keseimbangan antara keuntungan perpajakan di satu sisi dan di sisi lain biaya financial distress dan biaya kebangkrutan. Untuk menentukan titik keseimbangan ini, maka perusahaan harus mendapatkan fasilitas pinjaman, dimana kemungkinan atas biaya financial distress dapat ditutup dengan keuntungan pajak dari adanya hutang. Biaya kebangkrutan dan financial 
distress (Myers, 1977) serta biaya keagenan (Jensen dan Meckling, 1976) memberikan dasar bagi teori trade-off. Teori trade-off menyatakan bahwa perusahaan menetapkan rasio debt to value of firm dan secara bertahap berusaha mencapai target yang telah ditetapkan.

Teori struktur modal lain yang berkembang adalah teori pecking-order (Myers dan Majluf, 1984). Myers dan Majluf (1984) memakai asumsi bahwa para investor memiliki informasi yang tidak lengkap atas keadaan perusahaan (information asymmetry). Pada umumnya para investor tidak memiliki informasi sebanyak yang dimiliki oleh orang dalam, maka saham akan dinilai lebih rendah oleh investor. Asumsi lain yang dipakai adalah tidak adanya target struktur modal yang ditetapkan oleh perusahaan. Teori pecking order menyatakan bahwa perusahaan akan memilih pembiayaan sesuai dengan urutan tertentu, yaitu pembiayaan internal, diikuti dengan pembiayaan dari luar perusahaan. Pada saat perusahaan menggunakan pembiayaan dari luar perusahaan, maka perusahaan akan memilih hutang sebagai sekuritas yang paling aman, dilanjutkan dengan pinjaman konvertibel, dan urutan terakhir adalah ekuitas.

Penelitian empiris selanjutnya dikembangkan untuk menguji keandalan teori tersebut. Penelitian dilakukan atas faktor-faktor yang mempengaruhi struktur modal perusahaan, di mana faktor yang sering dipakai sebagai bahan pengujian di antaranya profitabilitas, tangibilitas, ukuran perusahaan, non-debt tax shields (NDTS), likuiditas dan usia perusahaan. Penjelasan masing-masing faktor dan penelitian terdahulu dijelaskan berikut ini.

Teori pecking-order dan teori trade-off memiliki penjelasan yang berbeda atas pengaruh profitabilitas terhadap struktur modal. Teori pecking order menunjukkan hubungan negatif sedangkan teori trade-off menunjukkan hubungan positif terhadap struktur modal (Myers dan Majluf, 1984). Menurut teori trade-off, profitabilitas perusahaan yang tinggi, akan makin meningkatkan kapasitas perusahaan untuk mendapatkan pinjaman dari luar. Dengan pinjaman dari luar yang makin tinggi, perusahaan akan mendapat keuntungan pajak dari tax-shield, sehingga profitabilitas berhubungan positif dengan struktur modal. Di sisi lain teori pecking-order menerangkan bahwa perusahaan dengan profitabilitas tinggi, cenderung akan lebih menggunakan modal sendiri dibandingkan dengan perusahaan dengan profitabilitas lebih rendah (Myers dan Majluf, 1984). Pada umumnya, pengujian empiris menemukan hubungan negatif antara profitabilitas dan struktur modal, seperti pada penelitian Huang dan Song (2002), Chen dan Strange (2005), Indrawati dan Suhendro (2006), Ali (2011) dan Liem et.al. (2013).

Tangibilitas merupakan merupakan jumlah aktiva tetap di dalam perusahaan. Menurut teori trade-off, terdapat hubungan positif antara jumlah aktiva tetap dengan rasio hutang, karena aktiva tetap menjadi jaminan bagi pembiayaan hutang. Perusahaan lebih mudah untuk mendapatkan hutang jika jumlah aktiva tetap makin besar (Myers dan Majluf, 1984; Harris dan Raviv, 1991). Dalam kaitan dengan jatuh tempo (maturity) hutang, menurut teori pecking order, proporsi aktiva tetap berhubungan positif dengan pembiayaan hutang jangka panjang, dan berhubungan negatif dengan pembiayaan jangka pendek. Hal ini ditemukan pada penelitian yang dilakukan oleh Myroschnichenko (2004). Sebagian besar penelitian mendapatkan bukti empiris hubungan positif antara tangibilitas dengan struktur modal seperti Ali (2011) di Pakistan, Liwang (2011) di Indonesia, Mouamer (2011) di Palestina dan Liem et.al (2013) di Indonesia. Hanya sebagian kecil penelitian yang menunjukkan korelasi signifikan negatif di antara kedua variabel, seperti penelitian Karadeniz et.al (2009) di Turki.

Ukuran dapat dilihat dari jumlah aktiva perusahaan, jumlah penjualan atau turnover, atau jumlah karyawan. Menurut teori trade-off, terdapat hubungan positif antara ukuran perusahaan dengan rasio hutang, karena perusahaan yang berukuran besar lebih terdiversifikasi dengan baik, arus kas yang lebih stabil dan memiliki lebih kecil kemungkinan untuk menunjukkan indikasi kebangkrutan (mengalami financial distress). Studi empiris yang telah dilakukan pada umumnya menemukan bahwa terdapat hubungan positif antara ukuran perusahaan dan rasio hutang, sehingga mendukung teori tradeoff (Harris dan Raviv, 1991; Huang dan Song, 2002; Indrawati dan Suhendro 2006). Sebaliknya, menurut teori pecking order terdapat hubungan negatif antara ukuran perusahaan dan rasio hutang, karena informasi yang asimetris bukan merupakan suatu masalah pada 
perusahaan besar. Jadi biaya modal dari perusahaan besar relatif akan lebih kecil dibandingkan dengan perusahaan kecil (Mouamer 2011).

Non-debt tax shield (NDTS) merupakan rasio dari total depresiasi per tahun dibandingkan dengan total aktiva. Menurut teori trade-off, NDTS berupa depresiasi dan amortisasi merupakan pendorong bagi perusahaan untuk mengurangi hutang, karena depresiasi dan amortisasi merupakan arus kas sebagai sumber modal dari dalam perusahaan sehingga dapat mengurangi pendanaan dari hutang. Menurut DeAngelo dan Masulis (1980), NDTS yang berupa pengurangan pajak dari depresiasi dan kredit pajak dari investasi merupakan pengganti dari keuntungan pajak (tax benefit) dari pembiayaan hutang. Oleh karena itu baik pada teori pecking-order maupun trade-off, NDTS diharapkan memiliki pengaruh negatif terhadap leverage (Myers dan Majluf, 1984). Perusahaan yang memiliki NDTS besar biasanya membukukan lebih sedikit hutang di dalam struktur modal mereka. Beberapa penelitian memperkuat kesimpulan ini, di antaranya Huang dan Song (2002) dan Liem et.al (2013).

Likuiditas (liquidity) diukur dengan rasio antara aktiva lancar dengan kewajiban lancar. Rasio ini menunjukkan penilaian likuiditas dan kemampuan perusahaan untuk membayar kewajiban keuangan jangka pendek yang telah jatuh tempo. Likuiditas dapat memiliki efek signifikan baik negatif atau positif terhadap struktur modal, sehingga efek bersihya tidak dapat ditentukan. Perusahaan yang dapat segera mengembalikan hutang-hutangnya akan mendapat kepercayaan dari kreditur untuk menerbitkan utang dalam jumlah besar. Menurut teori pecking order, perusahaan dengan likuiditas tinggi akan menerbitkan lebih sedikit hutang, karena saldo likuiditas akan digunakan perusahaan sebagai sumber pembiayaan investasi. Tapi perusahaan dengan likuiditas tinggi bisa juga memiliki rasio hutang yang tinggi, karena perusahaan ini memiliki kemampuan memadai untuk mendapatkan hutang terutama jangka pendek. Penelitian oleh Moamer (2011) atas 15 perusahaan publik di Palestina tahun 2000 - 2004, menunjukkan bahwa terdapat korelasi negatif antara likuiditas dengan total hutang, di mana perusahaan cenderung menggunakan likuiditasnya untuk membiayai investasi dibandingkan dengan mencari pembiayaan dari luar.

Dalam kaitan dengan usia, semakin lama perusahaan bergerak di dalam usahanya, maka lebih banyak informasi tersedia bagi kreditur untuk membuat keputusan, sehinga terdapat hubungan yang positif antara usia dan leverage (Petersen dan Rajan, 1994). Selain itu Perusahaan yang telah lama berdiri telah memiliki daya tahan, nama baik dan reputasi yang telah dibina bertahun-tahun. Penelitian yang dilakukan Akhtar dan Oliver (2009) atas perusahaan multinasional dan domestik di Jepang menunjukkan hubungan signifikan positif antara usia perusahaan dan leverage. Penelitian Chen dan Strange (2005) pada perusahaan terbuka di Shanghai dan Shenzhen China tahun 2003 menunjukkan bahwa usia perusahaan listing di pasar modal memiliki korelasi signifikan yang positif dengan nilai buku rasio hutang perusahaan.

\section{METODE}

\section{Data yang Dipakai}

Penelitian ini memakai data sekunder, yaitu laporan keuangan perusahaan yang terdaftar di Bursa Efek Indonesia (BEI) yang mengandung unsur variabel yang menjadi obyek penelitian. Penelitian ini menggunakan populasi perusahaan yang terdaftar menurut klasifikasi industri .yang telah ditetapkan oleh BEl yang diberi nama Jakarta Industrial Classification (JASICA). Populasi yang dipilih adalah perusahaan di dalam Sektor 5 dari JASICA yang berisikan Industri Barang Konsumsi pada tahun 2002 sampai dengan 2011, dan lebih spesifik yang diambil adalah klasifikasi emiten yaitu 51 - Makanan dan minuman, 52 - Produsen rokok, 53 - Industri farmasi, 54 - Kosmetika dan perawatan rumah, dan 55 - Barang kebutuhan rumah tangga.

Pengambilan sampel dan pemilihan perusahaan dalam penelitian ini dilakukan dengan melakukan metode purposive sampling, dengan kriteria sampel yang dipilih pertama perusahaan terdaftar di BEI pada tahun 2002 sampai dengan 2011 (ini berarti perusahaan harus listing pada atau sebelum tahun 2002, dan terdaftar sampai dengan 2011). Kedua perusahaan telah menerbitkan laporan keuangan yang telah diaudit oleh akuntan publik untuk tahun 2002 sampai dengan 2011. 
Dari hasil seleksi, terpilih perusahaan yang memenuhi syarat sebanyak total 29 perusahaan yang terdiri dari: 11 perusahaan makanan dan minuman, 3 perusahaan rokok, 9 perusahaan farmasi, 3 perusahaan kebutuhan personal dan 3 perusahaan barang rumahtangga.

\section{Variabel yang Digunakan}

Berdasarkan literatur dan penelitian sebelumnya, untuk penelitian ini akan digunakan enam faktor yang merupakan variabel independen, yang memiliki pengaruh terhadap struktur modal (Tabel 1).

Tabel 1 Variabel independen dan hubungan yang diharapkan dengan variabel dependen

\begin{tabular}{|c|c|c|c|}
\hline Variabel & Simbol & Pengukuran (Proksi) & $\begin{array}{l}\text { Hub antar } \\
\text { variabel yang } \\
\text { diharapkan }\end{array}$ \\
\hline Profitabilitas & PRO & EBIT / Total aktiva & $-1)$ \\
\hline Tangibility & TNG & Total aktiva tetap / Total aktiva & $-2)$ \\
\hline $\begin{array}{l}\text { Ukuran } \\
\text { perusahaan }\end{array}$ & SZE & Log (total aktiva) & $+3)$ \\
\hline $\begin{array}{l}\text { Non-debt } \\
\text { tax shields }\end{array}$ & NDT & Total depresiasi / Total aktiva & $-4)$ \\
\hline Likuiditas & LIQ & $\begin{array}{l}\text { Total aktiva lancar / Total } \\
\text { kewajiban lancar }\end{array}$ & $-5)$ \\
\hline $\begin{array}{l}\text { Usia } \\
\text { perusahaan }\end{array}$ & AGE & Usia perusahaan & $+6)$ \\
\hline
\end{tabular}

Keterangan:

1) Myroschnichenko (2004), Chen dan Strange (2005), Indrawati dan Suhendro (2006), Ali (2011), Liem et.al (2013); ${ }^{2)}$ Myroschnichenko (2004), Karadeniz et.al (2009); 3) Huang dan Song (2002), Myroschnichenko (2004), Ali (2011); 4) Huang dan Song (2002); Liem et.al (2013); 5) Mouamer (2011); ${ }^{6)}$ Chen dan Strange (2005), Akhtar dan Oliver (2009).

Sedangkan variabel dependen adalah struktur modal yang diukur dengan leverage (pengungkitan). Definisi pengungkitan adalah rasio dari total kewajiban terhadap total aktiva. Total kewajiban masih dapat dipilah lagi menjadi kewajiban jangka pendek dan jangka panjang. Kewajiban jangka pendek sebagian besarterdiridarihutang dagang, yang lebih merupakan faktor transaksi dibandingkan faktor pembiayaan. Sehingga untuk penelitian ini, akan digunakan tiga variabel dependen untuk lebih memperjelas efek variabel independen pada pengungkitan.

Untuk mengetahui faktor-faktor apa saja yang mempengaruhi struktur modal perusahaan barang konsumsi, maka dari variabel dependen dan independen, ditentukan hipotesis alternatif penelitian $(\mathrm{Ha})$ untuk masing-masing Total Leverage $(\mathrm{TL})$, Leverage Jangka Pendek (STL) dan Leverage Jangka Panjang (LTL) adalah sebagai berikut:

$\mathrm{H}_{\mathrm{a} 1} \quad$ : Profitabilitas berpengaruh negatif terhadap TL/STL/LTL

$\mathrm{H}_{\mathrm{a} 2} \quad$ : Tangibility berpengaruh negatif terhadap TL/ STL/LTL

$\mathrm{H}_{\mathrm{a} 3}$ : Ukuran perusahaan berpengaruh negatif terhadap TL/STL/LTL

$\mathrm{H}_{\mathrm{a} 4} \quad$ : NDTS berpengaruh negatif terhadap TL/STL/ LTL

$\mathrm{H}_{\mathrm{a} 5}$ : Likuiditas berpengaruh negatif terhadap TL/ STL/LTL

$\mathrm{H}_{\mathrm{a} 6}$ : Usia perusahaan berpengaruh negatif terhadap TL/STL/LTL

Tabel 2 Variabel independen Leverage yang digunakan

\begin{tabular}{lll}
\hline \multicolumn{1}{c}{ Variabel } & Simbol & \multicolumn{1}{c}{ Pengukuran } \\
\hline Total leverage & TL & Total kewajiban / Total aktiva \\
Leverage jangka pendek & STL & Total kewajiban jk.pendek / Total aktiva \\
Leverage jangka panjang & LTL & $\begin{array}{l}\text { Total kewajiban jk.panjang / Total } \\
\text { aktiva }\end{array}$ \\
\hline
\end{tabular}

\section{Metode Penelitian}

Penelitian ini menggunakan prosedur analisa regresi data panel karena sampel yang dipilih mengandung data-data periode antar waktu dan antar perusahaan. Untuk melakukan pengukuran atas pengaruh variabel bebas terhadap variabel terikat leverage (debt ratio), maka dipakai tiga jenis model estimasi, yaitu Pooled Ordinary Least Square (OLS), Fixed Effect Method (FEM) \& Random Effect Method (REM). Dari ketiga metode ini akan dipilih metode yang paling tepat, dengan bantuan uji Chow (memilih di antara Pooled OLS atau REM) atau uji-Hausman (memilih di antara FEM atau REM).

Persamaan matematis dari tiga estimasi model pengolahan data panel berturut-turut disajikan berikut ini:

Model matematis bagi PLS adalah:

$L E V_{i t}=\beta_{0}+\beta_{1} P R O_{i t}+\beta_{2} T N G_{i t}+\beta_{3} S Z E_{i t}+\beta_{4} N D T_{i t}+\beta_{5} L I Q_{i t}+\beta_{6} A G E_{i t}+\varepsilon_{i t}$

Sedangkan model matematis bagi FEM adalah:

$L E V_{i t}=\beta_{0}+\beta_{1} P R O_{i t}+\beta_{2} T N G_{i t}+\beta_{3} S Z E_{i t}+\beta_{4} N D T_{i t}+\beta_{5} L I Q_{i t}+\beta_{6} A G E_{i t}+u_{i t}$

Dan model matematis bagi REM adalah:

$L E V_{i t}=\beta_{0}+\beta_{1} P R O_{i t}+\beta_{2} T N G_{i t}+\beta_{3} S Z E_{i t}+\beta_{4} N D T_{i t}+\beta_{5} L I Q_{i t}+\beta_{6} A G E_{i t}+u_{i t}+\varepsilon_{i t}$ 
Dimana:

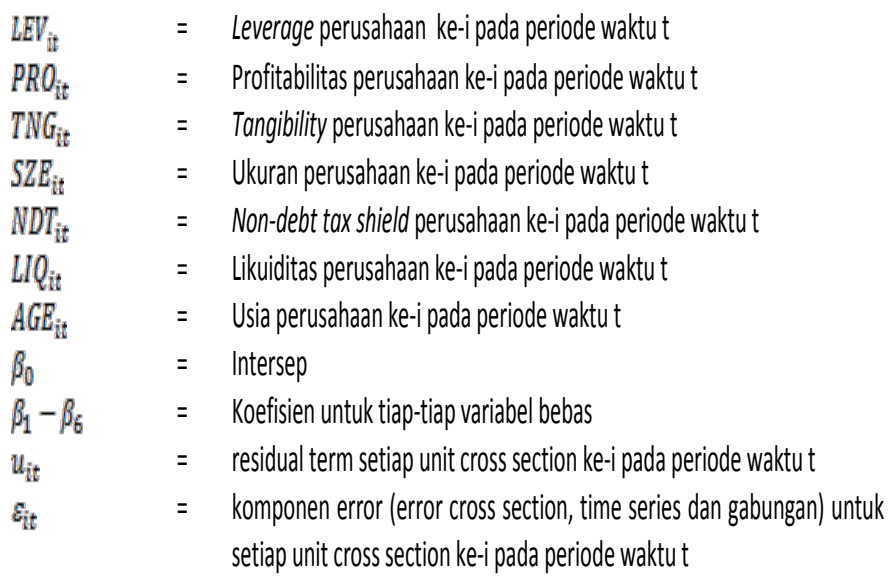

\section{HASIL DAN PEMBAHASAN}

Bagian ini menyajkan hasil pengolahan data dan menjelaskan implikasi dari pengolahan data. Tabel 3 menyajikan statistik deskriptif dari sampel. di tahun 2002 dan menurun pada $6.5 \%$ pada tahun 2011.

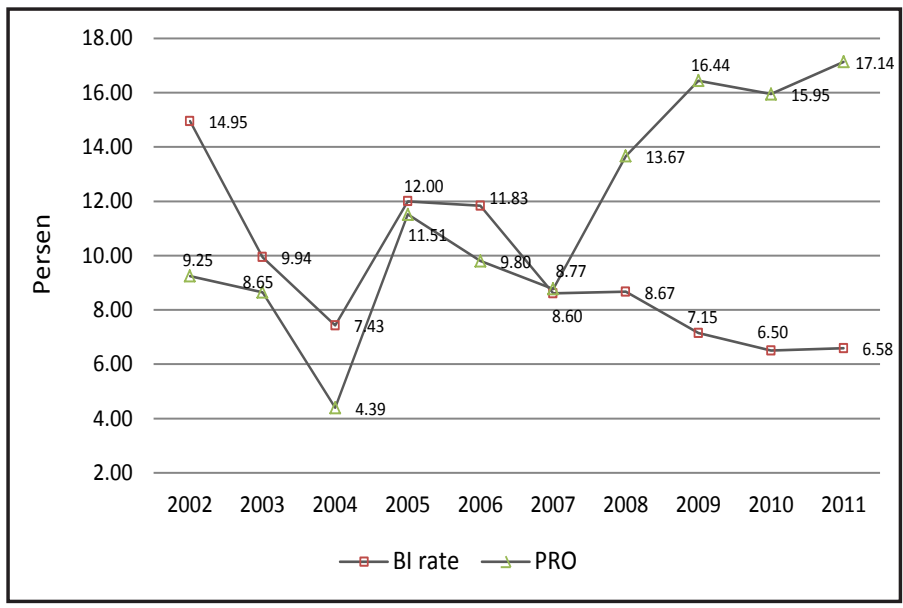

Gambar 2 Perbandingan PRO dengan suku bunga BI Periode 2002 - 2011

Tabel 3 Statistik deskriptif untuk seluruh sampel dan cross-section

\begin{tabular}{llllllllll}
\hline & \multicolumn{1}{c}{ TL } & \multicolumn{1}{c}{ STL } & \multicolumn{1}{c}{ LTL } & \multicolumn{1}{c}{ PRO } & TNG & SZE & NDT & LIQ \\
\hline Mean & 0.4952 & 0.3500 & 0.1452 & 0.1155 & 0.3510 & 13.654 & 0.0379 & 2.7330 \\
Median & 0.4065 & 0.2577 & 0.0626 & 0.0875 & 0.3128 & 13.259 & 0.0323 & 1.9600 & 35.279 \\
Maximum & 5.1584 & 5.1322 & 2.4486 & 0.9733 & 0.8363 & 17.796 & 0.2097 & 17.609 & 83 \\
Minimum & 0.0710 & 0.0310 & 0 & -1.440 & 0.0618 & 10.976 & 0.0095 & 0.1040 & 7 \\
Std. Dev. & 0.5270 & 0.3878 & 0.2660 & 0.2157 & 0.1662 & 1.5480 & 0.0238 & 2.2160 & 14.083 \\
Observations & 290 & 290 & 290 & 290 & 290 & 290 & 290 & 290 & 290 \\
Cross sections & 29 & 29 & 29 & 29 & 29 & 29 & 29 & 29 & 29 \\
\hline
\end{tabular}

Rasio kewajiban total adalah $49.52 \%$ yang berarti perusahaan di sektor ini cukup berimbang dalam membiayai aktivitasnya baik dari pinjaman atau modal sendiri. Rasio kewajiban jangka pendek dan kewajiban jangka panjang masing-masing sebesar $35.00 \%$ dan $14.52 \%$ menunjukkan bahwa pembiayaan dari pinjaman untuk sektor ini lebih banyak didapat dari rekanan dibandingkan dari pinjaman jangka panjang. Rasio kewajiban yang cukup signifikan ini didukung pula oleh nilai non-debt tax shields (NDTS) yang kecil di sektor ini senilai $3.79 \%$ dengan nilai tengah $3.23 \%$.

Rasio profitabilitas menunjukkan angka $11.55 \%$ dan nilai tengah $8.75 \%$, yang berarti sektor ini dapat memberikan rata-rata keuntungan $11.55 \%$ dari nilai aktiva yang dimiliki perusahaan. Angka pengembalian dari aktiva sebesar ini cukup tinggi, jika dibandingkan dengan tingkat suku bunga Bank Indonesia (BI) pada kurun waktu 2002 - 2011 yang berkisar mulai 14.95\%
Setelah krisis moneter berakhir di tahun 2000 dan suku bunga $\mathrm{BI}$ masih belum stabil (fluktuatif), rasio profitabilitas terlihat masih berfluktuasi mengikuti suku bunga BI. Pada saat krisis finansial dimulai tahun 2007 dimana BI melakukan kebijakan stabilitas dan penurunan tingkat suku bunga, profitabilitas sektor makanan dan minuman meningkat tinggi (Gambar 2). Pada saat BI menurunkan suku bunga dari kisaran $8 \%$ secara bertahap menuju tingkat $6.5 \%$, bank-bank nasional dan swasta tidak serta merta melakukan penyesuaian pada suku bunga tabungan, deposito dan bunga kredit. Hal ini menyebabkan perusahaan belum dapat secara optimal memanfaatkan penurunan suku bunga BI pada kredit perbankannya. Pada 2009 2010 setelah tingkat suku bunga BI sudah stabil, maka kondisi itu dapat dimanfaatkan perusahaan untuk mendapatkan pinjaman dengan tingkat suku bunga yang lebih rendah, sehingga mampu menstimulasi perusahaan untuk menangkap peluang investasi yang ada dan meningkatkan nilai perusahaan. Sehingga 
terlihat profitabilitas yang makin meningkat pada 2009 - 2011. Khususnya pada sektor makanan dan minuman serta barang konsumsi menikmati dampak kuatnya sektor riil dan tingkat konsumsi dalam negeri yang tetap meningkat.

Tingkat keuntungan ini dapat dicapai dari penggunaan aktiva tetap yang rata-rata senilai $35.10 \%$ dari total aktiva perusahaan, dan sisanya dari likuiditas dan modal kerja. Aktiva tetap merupakan bagian terbesar yang terdiri dari mesin manufaktur dan fasilitas produksi. Profitabilitas sektor ini juga cukup baik ditinjau dari rasio likuiditas dimana total aktiva lancar di sektor ini adalah 2.73 kali dari total kewajiban jangka pendeknya, dengan nilai tengah 1.96 kali.

Sebelum melakukan estimasi atas model regresi, maka sampel diuji terlebih dahulu terhadap multikolinearitas. Hasil uji korelasi Pearson disajikan pada Tabel 4, yang menunjukkan bahwa sebagian besar hubungan antar variabel dependen memiliki nilai di bawah (+/-) 0.6, sehingga dapat dianggap tidak ada permasalahan dengan multikolinearitas.

PRO menunjukkan korelasi signifikan positif dengan variabel SZE, LIQ dan AGE. Semakin besar ukuran perusahaan yang dilihat dari aktiva dan semakin lama perusahaan berbisnis, maka perusahaan makin menunjukkan profitabilitas. Sedangkan likuiditas di perusahaan barang konsumsi diperlukan untuk membiayai bahan baku dan kegiatan promosi untuk menunjang penjualan.
TNG memiliki korelasi negatif signifikan dengan PRO dengan arti adanya aktiva yang besar tidak serta merta meningkatkan profitabilitas, karena TNG tinggi mengurangi tingkat likuiditas (hubungan negatif dengan LIQ). SZE perusahaan berhubungan signifikan positif dengan AGE, dimana perusahaan manufaktur barang konsumsi umumnya mengalami peningkatan ukuran perusahaan sepanjang tahun.

Hasil dari pengolahan data statistik atas variabelvariabel dependen diringkas pada tabel-tabel berikut ini.

Untuk variable TL (Tabel 5), hasil uji Chow dan uji Hausman menunjukkan bahwa metode FEM merupakan metode yang paling tepat. Variabel yang menunjukkan hubungan yang signifikan adalah variabel PRO, TNG dan AGE (hubungan negatif), serta SZE (hubungan positif). Variabel yang tidak memiliki pengaruh terhadap variabel TL adalah NDT dan LIQ.

Hasil uji Chow dan uji Hausman atas variabel STL (Tabel 6) pada keseluruhan subsektor menunjukkan bahwa metode yang paling tepat adalah FEM. Variabel bebas yang memiliki pengaruh signifikan adalah PRO, TNG, LIQ dan AGE dengan hubungan negatif. Sedangkan variabel SZE dan NDT tidak memiliki pengaruh signifikan terhadap variabel STL.

Untuk variabel LTL (Tabel 7), hasil uji Chow dan uji Hausman menunjukkan bahwa metode FEM merupakan metode yang paling tepat. Variabel yang

Tabel 4 Tabel korelasi antar variabel independen

\begin{tabular}{|c|c|c|c|c|c|c|c|}
\hline & & PRO & TNG & SZE & NDT & LIQ & AGE \\
\hline \multirow[t]{2}{*}{ PRO } & Pearson Correlation & 1 & $-0.332^{* *}$ & $0.287^{* *}$ & $-0.342 * *$ & $0.210 * *$ & $0.526 * *$ \\
\hline & Sig. (2-tailed) & & 0.000 & 0.000 & 0.000 & 0.000 & 0.000 \\
\hline \multirow[t]{2}{*}{ TNG } & Pearson Correlation & $-0.332 * *$ & 1 & $-0.266^{* *}$ & $0.664 * *$ & $-0.349 * *$ & -0.057 \\
\hline & Sig. (2-tailed) & 0.000 & & 0.000 & 0.000 & 0.000 & 0.329 \\
\hline \multirow[t]{2}{*}{ SZE } & Pearson Correlation & $0.287^{* *}$ & $-0.266^{* *}$ & 1 & $-0.352 * *$ & -0.064 & $0.249 * *$ \\
\hline & Sig. (2-tailed) & 0.000 & 0.000 & & 0.000 & 0.280 & 0.000 \\
\hline \multirow[t]{2}{*}{ NDT } & Pearson Correlation & $-0.342 * *$ & $0.664 * *$ & $-0.352^{* *}$ & 1 & $-0.197 * *$ & 0.036 \\
\hline & Sig. (2-tailed) & 0.000 & 0.000 & 0.000 & & 0.001 & 0.543 \\
\hline \multirow[t]{2}{*}{ LIQ } & Pearson Correlation & $0.210 * *$ & $-0.349 * *$ & -0.064 & $-0.197 * *$ & 1 & 0.005 \\
\hline & Sig. (2-tailed) & 0.000 & 0.000 & 0.280 & 0.001 & & 0.935 \\
\hline \multirow[t]{2}{*}{ AGE } & Pearson Correlation & $0.526^{* *}$ & -0.057 & $0.249 * *$ & 0.036 & 0.005 & 1 \\
\hline & Sig. (2-tailed) & 0.000 & 0.329 & 0.000 & 0.543 & 0.935 & \\
\hline
\end{tabular}

**: Korelasi signifikan pada tingkat 0.01 (2-tailed). 
menunjukkan hubungan yang signifikan hanyalah variabel TNG dan AGE (hubungan negatif), sedangkan variabel PRO, SZE, NDT dan LIQ tidak memiliki hubungan yang signifikan.

Tabel 6 Hasil Pengolahan Data Panel Variabel Kewajiban Jangka Pendek (STL)

\begin{tabular}{lllll}
\hline \multicolumn{1}{c}{ Variabel } & & Pooled OLS & FEM & REM \\
\hline PRO & Koefisien & 0.0139 & -0.0506 & -0.0381 \\
& Prob. & 0.8811 & 0.5961 & 0.6753 \\
TNG & Koefisien & 0.0196 & -0.6325 & -0.2663 \\
& Prob. & 0.8795 & $* * 0.0007$ & 0.0818 \\
SZE & Koefisien & -0.0095 & 0.0359 & -0.0183 \\
& Prob. & 0.3908 & 0.5125 & 0.3652 \\
NDT & Koefisien & 0.4211 & 0.9762 & 0.8356 \\
& Prob. & 0.6481 & 0.4004 & 0.4199 \\
LIQ & Koefisien & -0.0180 & 0.0061 & -0.0065 \\
& Prob. & $* 0.0174$ & 0.5483 & 0.4624 \\
\hline AGE & Koefisien & -0.0039 & -0.0242 & -0.0052 \\
& Prob. & $* * 0.0040$ & $* * 0.0012$ & $* 0.0237$ \\
R-squared & & 0.0771 & 0.4475 & 0.0397 \\
Adjusted R-squared & & 0.0576 & 0.3738 & 0.0193 \\
F-statistic & & 3.9429 & 6.0750 & 1.9484 \\
Prob(F-statistic) & & 0.0008 & 0.0000 & 0.0731 \\
\hline$*$ of observations & & 290 & 290 & 290 \\
\hline
\end{tabular}

**signifikan pada tingkat 1\%

* signifikan pada tingkat 5\%

Tabel 7 Ringkasan hasil pengolahan data panel variabel LTL

\begin{tabular}{lllll}
\hline \multicolumn{1}{c}{ Variabel } & & Pooled OLS & \multicolumn{1}{c}{ FEM } & \multicolumn{1}{c}{ REM } \\
\hline PRO & Koefisien & 0.0139 & -0.0506 & -0.0381 \\
\multirow{2}{*}{ TNG } & Prob. & 0.8811 & 0.5961 & 0.6753 \\
& Koefisien & 0.0196 & -0.6325 & -0.2663 \\
SZE & Prob. & 0.8795 & $* * 0.0007$ & 0.0818 \\
& Koefisien & -0.0095 & 0.0359 & -0.0183 \\
NDT & Prob. & 0.3908 & 0.5125 & 0.3652 \\
\multirow{2}{*}{ LIQ } & Koefisien & 0.4211 & 0.9762 & 0.8356 \\
& Prob. & 0.6481 & 0.4004 & 0.4199 \\
AGE & Koefisien & -0.0180 & 0.0061 & -0.0065 \\
& Prob. & $* 0.0174$ & 0.5483 & 0.4624 \\
\multirow{2}{*}{ R-squared } & Koefisien & -0.0039 & -0.0242 & -0.0052 \\
Adjusted R-squared & & $* * 0.0040$ & $* * 0.0012$ & $* 0.0237$ \\
F-statistic & & 0.0771 & 0.4475 & 0.0397 \\
Prob(F-statistic) & & 0.0576 & 0.3738 & 0.0193 \\
\# of observations & & 3.9429 & 6.0750 & 1.9484 \\
\hline
\end{tabular}

Jurnal Bisnis \& Manajemen, 2015, Vol. XVI, No. 1, 47-59

**signifikan pada tingkat $1 \%$

* signifikan pada tingkat 5\%

Hasil pengujian faktor-faktor yang mempengaruhi struktur modal atas variabel total leverage (TL), leverage jangka pendek (STL) dan leverage jangka panjang (LTL), dirangkum di dalam Tabel berikut ini.

\section{Tabel 8 Ringkasan hasil pengujian pada variabel dependen TL, STL dan LTL.}

\begin{tabular}{|c|c|c|c|c|c|}
\hline Variabel & Simbol & $\mathrm{TL}$ & STL & LTL & $\begin{array}{l}\text { Hub variabel dependen dan } \\
\text { independen yang diharapkan }\end{array}$ \\
\hline Profitabilitas & PRO & - & - & 0 & $-1)$ \\
\hline Tangibility & TNG & - & - & - & $-2)$ \\
\hline $\begin{array}{l}\text { Ukuran } \\
\text { perusahaan }\end{array}$ & SZE & 0 & 0 & 0 & $+3)$ \\
\hline $\begin{array}{l}\text { Non-debt tax } \\
\text { shields }\end{array}$ & NDT & 0 & 0 & 0 & $-4)$ \\
\hline Likuiditas & LIQ & 0 & - & 0 & $-5)$ \\
\hline $\begin{array}{l}\text { Usia } \\
\text { perusahaan }\end{array}$ & AGE & - & - & - & $+6)$ \\
\hline \multicolumn{6}{|c|}{$\begin{array}{l}\text { 1) Myroschnichenko (2004), Chen dan Strange (2005), } \\
\text { Indrawati dan Suhendro (2006), Ali (2011), Liem et.al (2013); } \\
\text { Myroschnichenko (2004), Karadeniz et.al (2009); 3) Huang dan } \\
\text { Song (2002), Myroschnichenko (2004), Ali (2011); }{ }^{4)} \text { Huang dar } \\
\text { Song (2002); Liem et.al (2013); }{ }^{5)} \text { Mouamer (2011); }{ }^{6)} \text { Chen dan } \\
\text { Strange (2005), Akhtar dan Oliver (2009). }\end{array}$} \\
\hline
\end{tabular}

Profitabilitas untuk menunjukkan hubungan negatif dan signifikan dengan variabel total leverage (TL) dan leverage jangka pendek (STL), sedangkan profitabilitas tidak menunjukkan pengaruh yang signifikan terhadap variabel leverage jangka panjang. Secara umum, hasil ini sama dengan hubungan yang diharapkan berdasarkan penelitian-penelitian sebelumnya, yaitu penelitian Myers (1977) dan Myers dan Majluf (1984). Hubungan negatif ini terjadi karena perusahaan yang memiliki profitabilitas makin tinggi, lebih memilih untuk melakukan pembiayaan yang didanai oleh laba ditahan terlebih dulu, dilanjutkan dengan hutang, dan langkah terakhir jika diperlukan adalah menerbitkan ekuitas. Urutan pembiayan ini sesuai dengan teori pecking order.

Hubungan profitabilitas dengan leverage jangka panjang (LTL) tidak menunjukkan pengaruh yang signifikan merupakan konsekuensi dari kecenderungan untuk memakai pendanaan internal dari laba ditahan dibandingkan dengan hutang. Penelitian yang dilakukan oleh Myroschnichenko (2004) atas perusahaan di Ukrainia dan Chen (2007) 
pada perusahaan di Inggris menunjukkan bahwa variabel profitabilitas tidak signifikan secara statistik, sehingga dapat disimpulkan variabel ini tidak berpengaruh pada pertimbangan pembiayaan jangka panjang.

Tangibilitas menunjukkan pola arah yang sama dengan harapan, yaitu signifikan negatif. Penelitian yang dilakukan oleh Myroschnichenko (2004) di Ukrainia dan Karadeniz et.al (2009) di Turki menunjukkan bahwa hubungan negatif karena tangibilitas berhubungan dengan tingkat aktiva tetap dan investasi yang dibentuk perusahaan pada saat perusahaan akan melakukan perluasan atau penambahan kapasitas. Perusahaan barang konsumsi selalu melihat pasar sesuai dengan pertambahan penduduk, sehingga selalu menargetkan pertumbuhan dan pengembangan. Pertumbuhan ini membutuhkan penyediaan supply barang yang harus disediakan dengan penambahan kapasitas atau perluasan fasilitas produksi, yang membutuhkan investasi. Untuk membiayai investasi perusahaan akan melihat kepada likuiditas yang dimiliki, memakai pendanaan internal terlebih dulu dan perusahaan akan memakai pendanaan dari pinjaman hanya jika dana internal tidak memadai.

Ukuran perusahaan tidak menunjukkan hubungan yang signifikan dengan seluruh variabel independen leverage. Hal ini tidak sesuai dengan hasil sebagian besar penelitian, di antaranya Chen dan Strange (2005) dan Ali (2011). Tetapi jika dilihat dari hasil pengolahan data panel, walaupun tidak signifikan tanda hubungan antara ukuran perusahaan menunjukan tanda positif pada variabeI TL, STL dan LTL. Ini dapat diartikan bahwa di perusahaan manufaktur barang konsumsi, masih ada indikasi bahwa semakin besar ukuran perusahaan maka perusahaan makin memiliki leverage. Untuk membiayai pertumbuhan dan pengembangan perusahaan membutuhkan pinjaman. Tapi tidak bisa ditentukan apakah leverage ini untuk permodalan jangka pendek atau jangka panjang.

Non-debt tax shields (NDT) juga menunjukkan tidak adanya hubungan yang signifikan dengan seluruh variabel leverage. Hasil ini tidak konsisten dengan sebagian besar penelitian seperti Huang dan Song (2002) dan Liem et al. (2013). Hasil penelitian tersebut menunjukkan jika variabel NDT mengalami kenaikan maka akan menimbulkan penurunan atas variabel leverage. NDT merupakan penghematan pajak dari akun non-hutang, di antaranya biaya depresiasi, sehingga pengurangan pajak dari biaya depresiasi akan mensubstitusi manfaat pajak dari pendanaan dari pinjaman. Jika dilihat dari tanda hubungan variabel NDT dengan variabel leverage, terlihat hubungan negatif pada hubungan dengan TL dan STL, yang memang diharapkan dari penelitian sebelumnya.

Variabel likuiditas (LIQ) menunjukkan tidak adanya hubungan yang signifikan dengan variabel leverage TL dan LTL, serta hubungan yang signifikan negatif dengan leverage STL. Hal ini sesuai dengan hubungan yang diharapkan negatif, terutama dengan variabel leverage jangka pendek. Perusahaan yang memiliki likuiditas makin besar maka makin sedikit memiliki pinjaman, dan membayar kewajiban jangka pendek dengan likuiditas yang dimilikinya. Penelitian yang dilakukan oleh Mouamer (2011) atas perusahaan di Palestina menunjukkan variabel likuiditas memiliki hubungan negatif yang signifikan dengan variabel leverage jangka pendek dan leverage total.

Usia perusahaan (AGE) menunjukkan arah hubungan yang berbeda dengan arah hubungan yang diharapkan dari sebagian besar penelitian sebelumnya, yaitu hubungan yang positif. Hubungan yang positif ini menunjukkan bahwa perusahaan yang telah lama berdiri dan memiliki kredibilitas baik di mata kreditur, maka dapat lebih mudah mendapatkan fasilitas pembiayaan. Sedangkan hasil penelitian ini menunjukkan variabel AGE memiliki hubungan yang negatif dan signifikan dengan variabel leverage jangka pendek, jangka panjang, dan total. Penelitian ini menunjukkan bahwa dalam perusahaan barang konsumsi, semakin lama usia perusahaan, maka tingkat leverage perusahaan makin menurun, di mana perusahaan makin mengandalkan pembiayaan dari akumulasi modal.

\section{SIMPULAN}

Berdasarkan hasil pembahasan pada bagian sebelumnya, dapat diambil beberapa kesimpulan:

Pertama struktur modal di perusahaan barang konsumsi yang terdaftar di BEI tahun 2002 - 2011 
memiliki debt ratio sebesar $49 \%$. Tingkat debt ratio (kewajiban) tertinggi ada pada subsektor makanan dan minuman dan terendah ada pada subsektor kosmetika dan perawatan. Hal ini disebabkan karena subsektor makanan dan minuman memiliki perputaran persediaan dan barang yang cepat, ukuran perusahaan yang besar dan pasar yang terus berkembang (fast moving), sehingga kebutuhan akan bahan mentah terus meningkat. Tingkat total kewajiban sebesar $49 \%$ tersebut sebagian besar senilai 35\% adalah kewajiban jangka pendek dan sisannya adalah kewajiban jangka panjang. Komposisi ini hampir sama pada seluruh subsektor yang ada pada sektor makanan dan minuman.

Kedua dari hasil pengujian faktor yang mempengaruhi struktur modal terutama profitabilitas dan tangibilitas, baik pengujian pada masing-masing subsektor dan pengujian keseluruhan subsektor, terlihat bahwa perusahaan barang konsumsi selama tahun 2002 - 2011 memakai teori pecking order. Hal ini sejalan dengan literatur dan hasil penelitian terdahulu atas perusahaan manufaktur barang konsumsi (Myroschnichenko, 2004, Indrawati dan Suhendro, 2006 dan Chen 2007).

Ketiga hasil pengujian dan analisis pengaruh struktur modal terhadap leverage total (TL), variabel bebas PRO, TNG, SZE dan AGE memiliki pengaruh signifikan. Dengan R2 sebesar 54.9\%, maka diartikan 54.9\% perubahan dalam struktur modal perusahaan dalam sampel penelitian dapat diterangkan oleh variabel bebas tersebut. Variabel NDT dan LIQ tidak terbukti memiliki pengaruh signifikan terhadap struktur modal dan leverage total perusahaan.

Keempat pada analisis pengaruh struktur modal terhadap leverage jangka pendek (STL) menunjukkan hasil yang kurang lebih serupa dengan leverage total (TL), dimana variabel PRO, TNG dan AGE berpengaruh signifikan dan variabel NDT dan LIQ tidak berpengaruh signifikan. Hasil ini hanya sedikit berbeda dengan hasil yang diharapkan dari penelitian-penelitian sebelumnya pada variabel AGE. Sedangkan analisis pengaruh struktur modal terhadap leverage jangka panjang (LTL) memberikan hasil sedikit berbeda, yaitu hanya variabel TNG dan AGE yang berpengaruh signifikan dan variabel lainnya tidak berpengaruh. Hal ini menunjukkan bahwa variabel struktur modal lebih mempengaruhi leverage jangka pendek dibandingkan dengan leverage jangka panjang. Leverage jangka panjang pada perusahaan barang konsumsi tidak terlalu dipengaruhi oleh sebagian besar variabel struktur modal yang digunakan pada penelitian ini.

Penelitian ini memusatkan perhatian pada perusahaan barang konsumsi yang terdaftar di BEI pada kurun 2002 - 2011, dengan 6 variabel independen yang telah cukup banyak dijadikan bahan penelitian, dan memiliki prosentase $54.9 \%$ dapat menerangkan variabel dependennya. Tentu penelitian ini masih memiliki keterbatasan, sehingga ada beberapa hal yang dapat dilanjutkan dan dikembangkan pada penelitian selanjutnya di antaranya:

Pertama penambahan jumlah variabel independen seperti growth (Hovakimian et.al 2001), bankruptcy cost (Fama dan French, 2002), Agency Cost (Graflund, 2000).

Kedua penelitian pada kurun waktu sesudah krisis finansial 2008-2009 sampai dengan saat ini, dimana pasar modal Indonesia mengalami era yang baik dan kondusif.

Ketiga penelitian dapat pula memakai pengolahan data panel dengan metode yang berbeda, seperti yang dilakukan Lumbantobing (2008) dengan teknik estimasi Cochrane-Orcutt dan metode analisis data panel dinamis yang dilakukan oleh Karadenitz et.al. (2009) sebagai bahan pembanding dengan hasil yang didapat pada penelitian ini yang memakai regresi data panel dengan model Pooled OLS, Fixed Effect dan Random Effect dan bantuan software Eviews versi 6.0.

\section{DAFTAR PUSTAKA}

Akhtar, S., \& Oliver, B. (2009). Determinants of Capital Structure for Japanese Multinational and Domestic Corporations. International Review of Finance, 9, 1-26.

Ali, I. (2011). Determinants of capital structure: Empirical evidence from Pakistan. Disertasi Doktor. University of Twente Enschede.

Brealey, R. A., Myers, S. C., \& Allen, F. (2011). Principles 
of Corporate Finance 10th ed. 2. New York (US): McGraw-Hill

Chen, J., \& Strange, R. (2005). The Determinants of Capital Structure: Evidence from Chinese Listed Companies. Economic Change and Restructring, 38, 11-35.

Chen, L. (2007). Determinants of Capital Structure An Empirical Study from UK Firms. Disertasi Doktor. University of Nottingham UK.

DeAngelo, H., \& Masulis, R. (1980). Optimal Capital Structure under Corporate and Personal Taxation. Journal of Financial Economics, 8, 3-29.

Fama, E. F., \& French, K. R. (2002). Testing Trade-Off and Pecking Order Predictions About Dividends and Debt. The Review of Financial Studies, 15 (1), 1 - 33

Graflund, A. (2000). Dynamic Capital Structure: the Case of Hufvudstaden. Working Paper Nationalekonomiska Institutionen.

Harris, M., \& Raviv, A. (1991). The Theory of Capital Structure. Journal of Finance, 46, 297-355.

Hovakimian, A., Opler, T., \& Titman, S. (2001). The Debt-Equity Choice. Journal of Financial and Quantitative Analysis, 36(1)

Huang, S., \& Song, F., (2002). The Determinants of Capital Structure: Evidence from China, Working paper, The University of Hong Kong, 2-7.

Hukumonline. (2009). Davomas Abadi Terbelit Utang Bunga Obligasi. Diunduh dari http:// www.hukumonline.com/berita/baca/ hol22686/ tanggal 21 Juli 2014

Indrawati, T., \& Suhendro. (2006). Determinasi Capital Structure pada Perusahaan Manufaktur di Bursa Efek Jakarta periode 2000 - 2004. Jurnal Akuntansi dan Keuangan Indonesia, 3(1),77- 105.
Jensen, M., \& Meckling, W. (1976). Theory of the Firm: Managerial Behavior, Agency Costs, and Capital Structure. Journal of Financial Economics, 3, 305-360.

Karadeniz, E., Kandir, S. Y., Balcilar, M., \& Onal, Y. B. (2009). Determinants of capital structure: evidence from Turkish lodging companies. International Journal of Contemporary Hospitality Management,21 (5), 594-609.

Liem, J. H., Murhadi, W. R., \& Sutejo, B. S. (2013). Faktor-faktor yang Mempengaruhi Struktur Modal pada Industri Consumer Goods yang Terdaftar di BEl periode 2007 2011. Calyptra Jurnal Ilmiah Mahasiswa Universitas Surabaya, 2 (1), 1 -11.

Liwang, F. P. (2011). Analisis Faktor-faktor yang Mempengaruhi Struktur Modal serta Pengaruhnya terhadap Harga Saham pada Perusahaan-Perusahaan yang Tergabung dalam LQ45 Periode tahun 2006-2009. Prosiding Seminar Nasional Teknologi Informasi \& Komunikasi Terapan 2011; 16 April 2011; Semarang, Indonesia. Diunduh dari http://publikasi. dinus.ac.id/index.php/ semantic/article/view/13 tanggal 4 Mei 2013.

Lumbantobing, R. (2008). Studi Mengenai Perbedaan Struktur Modal Perusahaan Penanaman Modal Asing dengan Perusahaan Penanaman Modal Dalam Negeri yang Go Public di Pasar Modal Indonesia. Disertasi Doktor. Universitas Diponegoro Semarang.

Modigliani, F., \& Miller, M. H. (1958). The Cost of Capital, Corporate Finance, and the Theory of Investment. American Economic Review, 48, 261-297.

Modigliani, F., \& Miller, M. (1963). Corporate income taxes and the cost of capital: a correction. American Economic Review, 53, 433-443.

Mouamer, F. M. A. (2011). The determinants of capital structure of Palestine-listed companies. The Journal of Risk Finance, 12 (3),226-241 
Multi Bintang Indonesia PT. (2009). Laporan Tahunan 2009. Halaman 15

Myers, S. C. (1977). Determinants of corporate borrowing. Journal of Financial Economics, 5, 147-175.

Myers, S. C., \& Majluf, N. (1984). Corporate Financing and Investment Decisions when Firms have Information that Investors do not have. Journal of Financial Economics, 13, 187221.
Myroshnichenko, O. (2004). Determinants of Capital Structure of Ukrainian Corporations Disertasi Doktor. National University "KyivMohyla Academy" Kyiv (UKR).

Petersen, M. A., \& Raghuram, G. R. (1994). The Benefits of Lending Relationships: Evidence from Small Business Data. The Journal of Finance, 49 (1), $3-37$ 